\title{
Diprenylated Indole Alkaloids from Fruits of Hexalobus monopetalus
}

\author{
Hamisi M. Malebo $\cdot$ Stephan A. Jonker • \\ Reiner Waibel $\cdot$ Mayunga H. H. Nkunya
}

Received: 17 February 2014/ Accepted: 16 March 2014/Published online: 2 April 2014

(C) The Author(s) 2014. This article is published with open access at Springerlink.com

\begin{abstract}
New hexalobine type alkaloid, 5-(2", $3^{\prime \prime}$-epoxy-3"'-methylbutyl)-3-(3'-hydroxy-3'-methyl-1'-acetyloxy-but-2'-

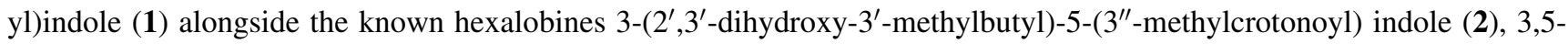
hexalobine C (3) and 3,5-hexalobine D (4) were isolated from fruits of Hexalobus monopetalus. Compounds 3 and 4 exhibited antifungal activity against Candida albicans.
\end{abstract}

Keywords Hexalobus monopetalus $\cdot$ Hexalobines $\cdot$ Indole alkaloids $\cdot$ Candida albicans

\section{Introduction}

Hexalobus is one of the genera of the family Annonaceae which is confined to the Savannah region of tropical Africa. It is a relatively small genus of about six species comprising of erect shrubs or small trees $[1,2]$. Only Hexalobus monopetalus is known to occur in Tanzania, being found in Coast, Iringa, Kigoma, Mbeya, Mwanza, Ruvuma and Tabora regions where it is used for the treatment of stomach disorders and fevers [3].

The crude extracts from the root bark of H. monopetalus exhibited cytotoxicity in the brine shrimp lethality test with $\mathrm{IC}_{50}$ values ranging from 0.56 to $66.07 \mu \mathrm{g} / \mathrm{mL}$ [3]. In the antimalarial test, the crude ethanolic root bark extract was

\section{H. M. Malebo $(\square)$}

Department of Traditional Medicine Research, National Institute for Medical Research, P.O. Box 9653, Dar es Salaam, Tanzania e-mail: Malebo@hotmail.com

S. A. Jonker - M. H. H. Nkunya

Department of Chemistry, University of Dar es Salaam, P.O.

Box 35061, Dar es Salaam, Tanzania

R. Waibel

Department of Pharmaceutical Chemistry, Institute of Pharmacy, University of Erlangen, Schuhstrasse 19, 91052 Erlangen, Germany mildly active against the multidrug resistant $\mathrm{K} 1$ and chloroquine sensitive NF 54 strains of Plasmodium falciparum, with $\mathrm{IC}_{50}$ values of 9.9 and $13 \mu \mathrm{g} / \mathrm{mL}$, respectively [3]. The same extract exhibited trypanocidal activity against Trypanosoma brucei rhodesiense, with a minimum inhibition concentration of $11 \mu \mathrm{g} / \mathrm{mL}$ [3]. These results prompted us to investigate crude extracts from the fruits of $H$. monopetalus for bioactive constituents. Furthermore, the fruits of $H$. monopetalus which are edible to primates and humans, were not hitherto investigated for their phytochemical constituents and hence were considered to be a target for these studies that formed part of long-term investigations of Annonaceae species occurring in Tanzania. This investigation resulted in the isolation of one new hexalobine type alkaloid compound $\mathbf{1}$ alongside the known hexalobines 3-(2',3'-dihydroxy-3'-methylbutyl)-5(3"-methylcrotonoyl) indole (2), 3,5-hexalobine C (3) and 3,5-hexalobine D (4) (Fig. 1). The structures of hexalobines were determined on the basis of spectroscopic analysis including NMR, MS, IR data and by comparison with data reported in literature [4-7].

\section{Results and Discussion}

5-(2", $3^{\prime \prime}$-Epoxy-3" -methylbutyl)-3-(3'-hydroxy-3'-methyl$1^{\prime}$-acetyloxybut-2'-yl)indole (1) was obtained as a colorless 
<smiles>[CH]C([CH])(O)C(=COC(C)=O)c1c[nH]c2ccc(C[C]3OC3(C)C)cc12</smiles><smiles>CC1(C)OC1Cc1ccc2[nH]cc(CC3OC3(C)S)c2c1</smiles>

Fig. 1 Structures of compounds 1-4

oil. The molecular formula $\mathrm{C}_{20} \mathrm{H}_{27} \mathrm{NO}_{4}$ was established on the basis of ${ }^{1} \mathrm{H},{ }^{13} \mathrm{C}$ NMR (Tables 1, 2), and EI-MS, and on comparison of the spectroscopic properties of hexalobines reported in the literature. The ${ }^{1} \mathrm{H}$ NMR spectrum revealed the presence of five low field proton signals, which were attributed to a disubstituted indole skeleton $[5,6]$. The broad singlet at $\delta 8.12(1 \mathrm{H})$ is typical for an indoyl $\mathrm{N}-\mathrm{H}$ proton, the broadening of the signal arising from the quadrupole broadening effect of nitrogen [8]. The signal at $\delta 7.12(1 \mathrm{H}, J=2, \mathrm{H}-2)$ appeared as a doublet due to coupling with an indoyl $\mathrm{N}-\mathrm{H}$, thus suggesting that $\mathrm{C}-3$ on the indoyl moiety is substituted, as confirmed by the absence of an H-3 resonance at ca. $\delta 6.50$ [7, 8]. Another low field signal appeared at $\delta 7.49(1 \mathrm{H}, \mathrm{H}-4)$ as a broad singlet and the presence of this signal indicated substitution at the indoyl position 5, as further revealed by the absence of an H-5 signal at ca. $\delta 6.99[7,8]$. Two signals of orthocoupled aromatic protons appeared at $\delta 7.34(\mathrm{~d}, 1 \mathrm{H}, J=8.0$ $\mathrm{Hz}, \mathrm{H}-7$ ) and at $\delta 7.10$ (dd, $1 \mathrm{H}, J=8.0,1.5 \mathrm{~Hz}, \mathrm{H}-6)$ [4]. These indicated that the indole unit had a 1,2,4 arrangement of protons on the benzene ring [7].

The ${ }^{13} \mathrm{C}$ NMR spectrum (Table 2) confirmed the presence of the 3,5-disubstituted indole nucleus as the methine $\mathrm{C}$ signals which normally resonate at ca. $\delta 102.10$ for C-3 and at ca. $\delta 121.7$ for C-5 in a typical unsubstituted indole alkaloid [7], now appeared as quaternary $\mathrm{C}$ signals at $\delta 113.5$ and $\delta 129.3$, respectively. Other indole $\mathrm{C}$ signals appeared in the anticipated chemical shifts typical for the indole nucleus (Table 2).<smiles>CC(C)=CC(=O)c1ccc2[nH]cc(CC(O)C(C)(C)O)c2c1</smiles><smiles>CC(C)=CC(=O)c1ccc2[nH]cc(CC3OC3(C)S)c2c1</smiles>

An ABX spin system was observed for $\mathbf{1}$, with signals at $\delta_{\mathrm{HA}}=4.52\left(\mathrm{H}-1^{\prime} \alpha\right), \delta_{\mathrm{HB}}=4.59\left(\mathrm{H}-1^{\prime} \beta\right)$ and $\delta_{\mathrm{HX}}=3.41$ $\left(\mathrm{H}-2^{\prime}, J_{\mathrm{AB}}=11.5, J_{\mathrm{AX}}=7.5, J_{\mathrm{BX}}=6.5 \mathrm{~Hz}\right)$. The low field position of the $A B$ methylene signals suggested that the methylene group in $\mathbf{1}$ was not directly connected to the indole moiety as in $\mathbf{2}$, but with clear difference due to a stronger deshielding substituent which, based on the presence of a carbonyl absorption at $\delta 171.1$ in the ${ }^{13} \mathrm{C}$ NMR spectrum and a methyl $\mathrm{H}$ absorption at $\delta 1.95$, was concluded to be an acetoxy group. The existence of the downfield ${ }^{1} \mathrm{H}$ NMR resonances of $1^{\prime} \alpha$ at $\delta 4.52(\mathrm{dd}, 11.5,7.5)$ and $1^{\prime} \beta$ at $\delta 4.59(\mathrm{dd}$, $11.5,6.5$ ) as compared with other hexalobines, confirms that electron-withdrawing group is nearby the germinal protons and the only possibility is the acetoxy group. Further analysis of the ${ }^{1} \mathrm{H}$ NMR spectroscopic data confirmed the diastereotopic protons $1^{\prime} \alpha$ and $1^{\prime} \beta$ are coupling with the methine resonating at $\delta 3.41\left(\mathrm{dd}, 7.5,6.5, \mathrm{H}-2^{\prime}\right)$. The prenyl linkage indicated by ${ }^{1} \mathrm{H}$ NMR involving the acetoxy group, the diastereotopic protons and the methine led to only one structural possibility for $\mathbf{1}$. While all the functional groups are well accommodated for in this structure, any other structural placement of the acetoxy group lacks support of ${ }^{1} \mathrm{H}$ NMR spectroscopic data. Fortunately, there exist no any possible spectroscopic ambiguities in the placement of the acetoxy group in position $1^{\prime}$.

The MS of 1 exhibited the $\mathrm{M}^{+}$peak at $\mathrm{m} / \mathrm{z} 345$ corresponding to a molecular formula $\mathrm{C}_{20} \mathrm{H}_{27} \mathrm{NO}_{4}$. The odd mass of the EI-MS base peak at $m / z 227\left(\mathrm{C}_{15} \mathrm{H}_{17} \mathrm{NO}^{+}\right)$implied its 
Table $1{ }^{1} \mathrm{H}$ NMR data of compounds 1-4

\begin{tabular}{|c|c|c|c|c|}
\hline \multirow[t]{2}{*}{$\mathrm{H}$} & \multicolumn{4}{|l|}{$\delta_{\mathrm{H}} \mathrm{J}(\mathrm{Hz})$} \\
\hline & 1 & 2 & 3 & 4 \\
\hline 1 & 8.12 br. s & 8.39 br. s & 7.99 br. s & 8.76 br. s \\
\hline 2 & $7.12 \mathrm{~d}(2)$ & $7.17 \mathrm{~d}(2)$ & $\begin{array}{r}7.07 \mathrm{~d} \\
(2.1)\end{array}$ & $7.11 \mathrm{~d}(2)$ \\
\hline 4 & 7.49 br. s & 8.26 br. s & 7.49 br. s & 8.30 br. $\mathrm{s}$ \\
\hline 6 & $\begin{array}{l}7.10 \mathrm{dd} \\
\quad(8.0,1.5)\end{array}$ & $\begin{array}{l}7.85 \text { dd (8.0, } \\
1.5)\end{array}$ & $\begin{array}{l}7.27 \mathrm{dd} \\
\quad(8.1,1.5)\end{array}$ & $\begin{array}{l}7.86 \mathrm{dd} \\
\quad(8.5,1.5)\end{array}$ \\
\hline 7 & $7.34 \mathrm{~d}(8.0)$ & $7.37 \mathrm{~d}(8.5)$ & $\begin{array}{r}7.05 \mathrm{~d} \\
(8.1)\end{array}$ & $\begin{array}{r}7.35 \mathrm{~d} \\
(8.5)\end{array}$ \\
\hline $1^{\prime} \mathrm{a}$ & $\begin{array}{c}4.52 \mathrm{dd} \\
(11.5 \\
7.5)\end{array}$ & $\begin{array}{l}2.80 \mathrm{dd}(14.5 \\
10.5)\end{array}$ & $3.06 \mathrm{~m}$ & $3.03 \mathrm{~m}$ \\
\hline $1^{\prime} \mathrm{b}$ & $\begin{array}{c}4.59 \mathrm{dd} \\
\quad(11.5 \\
6.5)\end{array}$ & $\begin{array}{l}3.09 \mathrm{dd}(14.5 \\
2.5)\end{array}$ & - & - \\
\hline $2^{\prime}$ & $\begin{array}{l}3.41 \mathrm{dd} \\
\quad(7.5,6.5)\end{array}$ & $\begin{array}{l}3.75 \text { ddd }(10.5 \\
2.5,2.5)\end{array}$ & $2.93 \mathrm{~m}$ & $3.09 \mathrm{~m}$ \\
\hline $4^{\prime}$ & $1.28^{\mathrm{a}} \mathrm{s}$ & $1.33^{\mathrm{a}} \mathrm{s}$ & $1.34^{\mathrm{a}} \mathrm{s}$ & $1.36^{\mathrm{a}} \mathrm{s}$ \\
\hline $5^{\prime}$ & $1.31^{\mathrm{a}} \mathrm{s}$ & $1.36^{\mathrm{a}} \mathrm{s}$ & $1.44^{\mathrm{a}} \mathrm{s}$ & $1.45^{\mathrm{a}} \mathrm{s}$ \\
\hline $1^{\prime \prime} \mathrm{a}$ & $2.91 \mathrm{~m}$ & - & $3.06 \mathrm{~m}$ & $2.91 \mathrm{~m}$ \\
\hline $1^{\prime \prime} \mathrm{b}$ & $2.9-3.1 \mathrm{~m}$ & - & - & $2.9-3.1 \mathrm{~m}$ \\
\hline $2^{\prime \prime}$ & $2.9-3.1 \mathrm{~m}$ & $\begin{array}{l}6.84 \mathrm{qq}(1.5 \\
1.5)\end{array}$ & $2.93 \mathrm{~m}$ & $6.86 \mathrm{~m}$ \\
\hline $4^{\prime \prime}$ & $1.35 \mathrm{~s}$ & $2.04 \mathrm{~d}(1.5)$ & $1.35^{\mathrm{b}} \mathrm{s}$ & $\begin{array}{c}2.04^{\mathrm{b}} \mathrm{d} \\
(1.5)\end{array}$ \\
\hline $5^{\prime \prime}$ & $1.44 \mathrm{~s}$ & $2.21 \mathrm{~d}(1.5)$ & $1.44^{\mathrm{b}} \mathrm{s}$ & $\begin{array}{c}2.20^{\mathrm{b}} \mathrm{d} \\
(1.5)\end{array}$ \\
\hline $\mathrm{OH}$ & 1.82 br. $\mathrm{s}$ & 2.17 br. d (2.5) & - & - \\
\hline $\mathrm{OH}$ & - & 2.26 br. s & - & - \\
\hline$-\mathrm{OCOCH}_{3}$ & $1.95 \mathrm{~s}$ & - & - & - \\
\hline
\end{tabular}

a,b Signals interchangeable within a column

formation being through a rearrangement reaction, which is feasible due to the presence of the acyl substituent in $\mathbf{1}$ (Scheme 1). Loss of the epoxyisobutylene group from the fragment ion at $m / z 227\left(\left[\mathrm{C}_{15} \mathrm{H}_{17} \mathrm{NO}\right]^{+}\right)$could explain the formation of the fragment ion at $m / z, 156\left(\left[\mathrm{C}_{11} \mathrm{H}_{10} \mathrm{~N}\right]^{+}\right)$. The subsequent loss from the molecular ion of a methyl radical and $\mathrm{CO}_{2}$, as indicated by the appearance of fragment ions at $\mathrm{m} / \mathrm{z}$ $330\left(\left[\mathrm{C}_{19} \mathrm{H}_{24} \mathrm{NO}_{3}\right]^{+}\right)$and $286\left(\left[\mathrm{C}_{18} \mathrm{H}_{24} \mathrm{NO}_{2}\right]^{+}\right)$respectively, confirmed the presence of an acetyl group in structure $\mathbf{1}$.

Compound $\mathbf{1}$ is hitherto not been reported but the presence of an acetyl group in this prenyl indole immediately led to the suspicion that the compound might be an artefact, being formed through transesterification of the corresponding hydroxy compound with acidic ethyl acetate used in the isolation process. However, it can also be argued that acidic conditions favouring transesterification with ethyl acetate during the isolation process would invariably also open the epoxide ring on the C-5 prenyl group. Apparently, a diol of $\mathbf{1}$ thought to be formed this way was not obtained when $\mathbf{1}$ was
Table $2{ }^{13} \mathrm{C}$ NMR data of compounds $1-4$

\begin{tabular}{|c|c|c|c|c|}
\hline \multirow[t]{2}{*}{$\mathrm{C}$} & \multicolumn{4}{|l|}{$\delta_{\mathrm{C}}$} \\
\hline & 1 & 2 & 3 & 4 \\
\hline 2 & $122.6, \mathrm{CH}$ & $124.0, \mathrm{CH}$ & $122.11, \mathrm{CH}$ & $123.2, \mathrm{CH}$ \\
\hline 3 & $113.5, \mathrm{C}$ & $114.5, \mathrm{C}$ & 112.27, C & $114.0, \mathrm{C}$ \\
\hline $3 a$ & $128.6, \mathrm{C}$ & $127.2, \mathrm{C}$ & $127.83, \mathrm{C}$ & $127.1, \mathrm{C}$ \\
\hline 4 & $119.2, \mathrm{CH}$ & $122.0, \mathrm{CH}$ & $118.62, \mathrm{CH}$ & $120.9, \mathrm{CH}$ \\
\hline 5 & $129.3, \mathrm{C}$ & $131.5, \mathrm{C}$ & $129.02, \mathrm{C}$ & $131.0, \mathrm{C}$ \\
\hline 6 & $123.3, \mathrm{CH}$ & $120.6, \mathrm{CH}$ & 123.26, CH & $122.7, \mathrm{CH}$ \\
\hline 7 & $111.2, \mathrm{CH}$ & $111.0, \mathrm{CH}$ & $111.20, \mathrm{CH}$ & $111.0, \mathrm{CH}$ \\
\hline $7 \mathrm{a}$ & $134.8, \mathrm{C}$ & $139.0, \mathrm{C}$ & $135.19, \mathrm{C}$ & $138.5, \mathrm{C}$ \\
\hline $1^{\prime}$ & $65.2, \mathrm{CH}_{2}$ & $28.0, \mathrm{CH}_{2}$ & $24.90, \mathrm{CH}_{2}$ & $25.1, \mathrm{CH}_{2}$ \\
\hline $2^{\prime}$ & $46.2, \mathrm{CH}$ & $78.0, \mathrm{CH}$ & $64.11, \mathrm{CH}$ & $64.0, \mathrm{CH}$ \\
\hline $3^{\prime}$ & 72.7, C & 73.0, C & $58.69, \mathrm{C}$ & 58.6, C \\
\hline $4^{\prime}$ & $28.3, \mathrm{CH}_{3}$ & $26.5, \mathrm{CH}_{3}$ & $24.86, \mathrm{CH}_{3}$ & $24.9, \mathrm{CH}_{3}$ \\
\hline $5^{\prime}$ & $28.0, \mathrm{CH}_{3}$ & $23.9, \mathrm{CH}_{3}$ & $18.72, \mathrm{CH}_{3}$ & $19.0, \mathrm{CH}_{3}$ \\
\hline $1^{\prime \prime}$ & $35.5, \mathrm{CH}_{2}$ & 193.0, $\mathrm{C}=\mathrm{O}$ & $35.53, \mathrm{CH}_{2}$ & $192.3, \mathrm{C}=\mathrm{O}$ \\
\hline $2^{\prime \prime}$ & $65.1, \mathrm{CH}$ & $123.0, \mathrm{CH}$ & $65.19, \mathrm{CH}$ & $122.4, \mathrm{CH}$ \\
\hline $3^{\prime \prime}$ & 58.7, C & 154.0, C & $58.69, \mathrm{C}$ & 154.0, C \\
\hline $4^{\prime \prime}$ & $24.9, \mathrm{CH}_{3}$ & 27.0, $\mathrm{CH}_{3}$ & $24.86, \mathrm{CH}_{3}$ & $27.4, \mathrm{CH}_{3}$ \\
\hline $5^{\prime \prime}$ & $19.0, \mathrm{CH}_{3}$ & $20.9, \mathrm{CH}_{3}$ & $18.88, \mathrm{CH}_{3}$ & $21.0, \mathrm{CH}_{3}$ \\
\hline$-\mathrm{CH}_{3}$ & 29.7 & - & - & - \\
\hline$-\mathrm{C}=\mathrm{O}$ & 171.1 & - & - & - \\
\hline
\end{tabular}

re-subjected to the isolation conditions using the same ethyl acetate as before. Furthermore, compound $\mathbf{1}$ was already detected in the crude extract which had hitherto not been subjected to chromatography in ethyl acetate. It is therefore concluded that $\mathbf{1}$ is a genuine natural product and not an artefact. Similar acyl bisprenylindoles have previously been isolated from H. crispiflorus [1, 3]. Biogenetically, hexalobines with an ester functionality like other hexalobines are conceived to be biosynthesised in these plants from tryptophan, and two $\mathrm{C}_{5}$ isoprene units from the isoprene pathway to form diprenyl indole skeleton (see Scheme 1.1) [1].

Compounds 3 and $\mathbf{4}$ exhibited very mild antifungal activity against Candida albicans, with zones of inhibition of 5 and $14 \mathrm{~mm}$ at a concentration of $100 \mu \mathrm{g} / \mathrm{mL}$, respectively. In the previous investigations compound $\mathbf{4}$ exhibited antifungal activity against Botrytis cinerea, Rhizoctonia solani and Saprolegnia asterophora with zones of inhibition of 5, $5-12$ and 5-12 at a concentration of $150 \mu \mathrm{g} / \mathrm{mL}$ [4].

\section{Experimental Section}

\subsection{General Experimental Procedures}

Infrared (IR) spectra, taken in chloroform solutions were recorded on a Shimadzu Model IR-435 spectrophotometer 


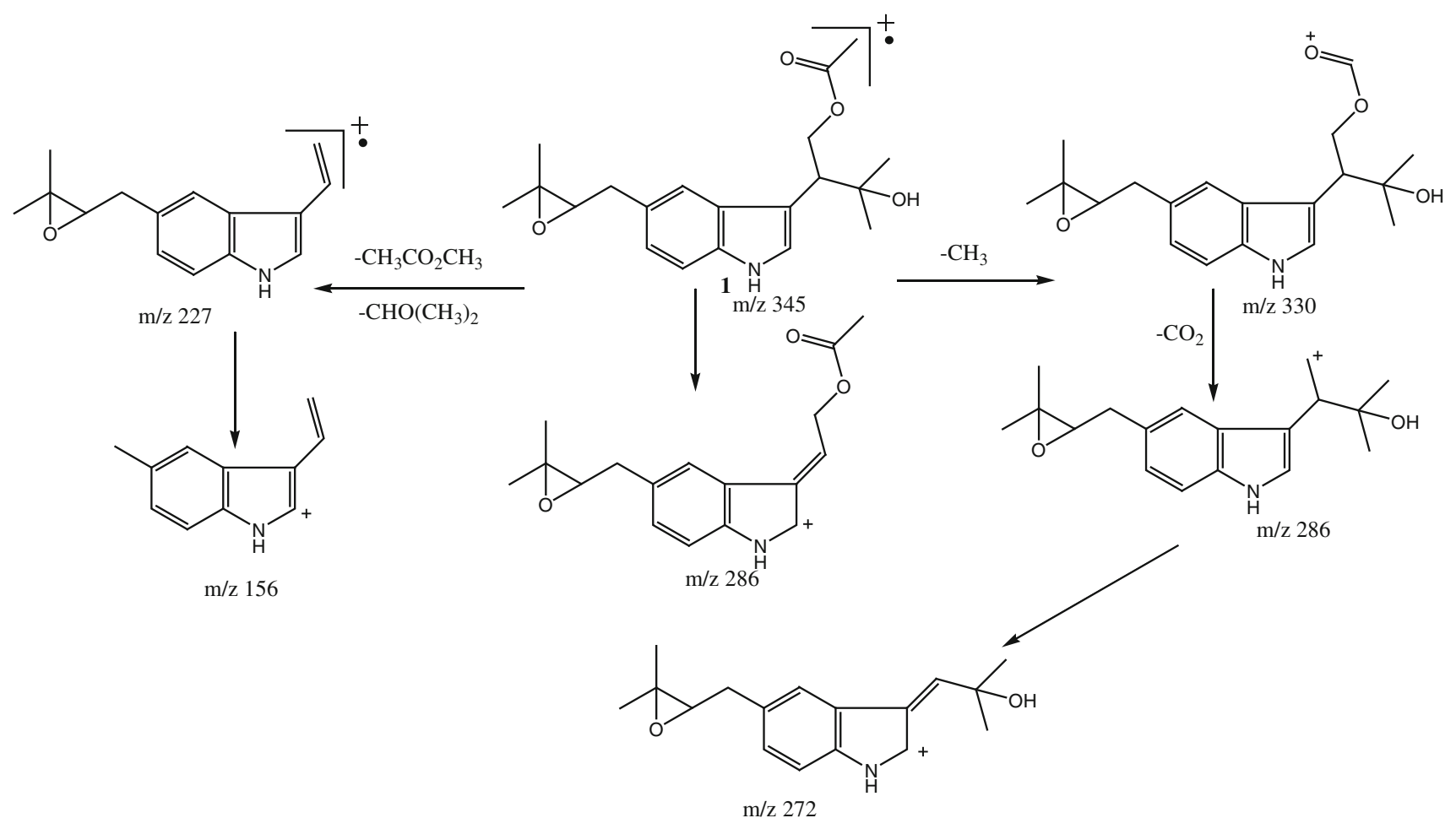

Scheme 1 Mass spectral fragmentation pattern of 5-(2", $3^{\prime \prime}$-epoxy-3"'-methylbutyl)-3-(3'-hydroxy-3'-methyl-1'-acetyloxybut-2'-yl)indole (1)

with absorptions given in wave numbers $\left(\mathrm{cm}^{-1}\right) .{ }^{1} \mathrm{H}$ NMR spectra were recorded on either a Bruker AM 360 instrument operating at $360 \mathrm{MHz}$ with $\mathrm{CDCl}_{3}$ was used as solvent at the Institute of Pharmacy, University of Erlangen in Germany. Column chromatography was carried out with silica gel (200-300 mesh) and Sephadex LH-20 (Amersham Biosciences, Sweden). Fractions were monitored by thin layer chromatography (TLC). Visualization of TLC spots was done under UV light at 254 or $366 \mathrm{~nm}$ and by spraying with an anisaldehyde reagent. Detection was done under UV light at 254 or $366 \mathrm{~nm}$. Vacuum liquid chromatography (VLC) was carried out using normal phase silica gel [of particle size 400 Mesh ASTM (Merck)] and gradient elution was applied. The vacuum was generated from a membrane pump.

\subsection{Plant Materials}

The fruits of H. monopetalus were collected from Ugowola village in Tabora District in Tanzania. Identification of the plant species was done at the Herbarium of the Department of Botany, University of Dar es Salaam where a voucher specimen has been deposited (Manoko collection No. 0046-98).

\subsection{Extraction and Isolation of Compounds}

The air dried and pulverised fruits of $H$. monopetalus $(1 \mathrm{~kg}$ ) were soaked in ethanol for $48 \mathrm{~h}$ at room temperature (about $30{ }^{\circ} \mathrm{C}$ ). The crude extract was obtained by filtration, followed by concentration of the filtrate in vacuo using a rotary evaporator maintained at $30{ }^{\circ} \mathrm{C}$ so as to avoid decomposition of thermally unstable compounds. The resulting extract weighed $30 \mathrm{~g}$. The crude extract was fractionated by VLC eluting with pet ether containing increasing amounts of ethyl acetate and then a mixture of methanol and ethyl acetate. The first five fractions contained a complex mixture of non-polar compounds and therefore they were not analyzed further. The combined 6th to 10th VLC fractions were separated by flash column chromatography on silica gel eluting with a $3: 7(\mathrm{v} / \mathrm{v})$ mixture of ethyl acetate and pet ether, then gradually increasing the gradient to $1: 1(\mathrm{v} / \mathrm{v})$ and finally with only ethyl acetate. This yielded 72 fractions which were combined to 13 based on TLC similarities. On repeated column chromatography of VLC fraction 11, 12 and 13 led to the isolation of hexalobines which were purified by chromatography on Sephadex ${ }^{\circledR}$ LH-20 (MeOH).

\subsection{Antifungal Tests}

The antifungal assay to evaluate the ability of the pure compounds to inhibit growth of $C$. albicans in a culture media was carried out using the standard plate diffusion method. The medium was prepared as follows: $32.50 \mathrm{~g}$ of Sabouraud Dextrose Agar was mixed with $500 \mathrm{~mL}$ of 
sterile distilled water. The mixture was sterilized by autoclaving at $120{ }^{\circ} \mathrm{C}$ for 15 min under 1 bar pressure. Under aseptic conditions in the laminar flow hood, the medium was dispensed into $150 \mathrm{~mm}$ pre-sterilized petri dishes to yield a uniform depth of $4 \mathrm{~mm}$. They were then covered and allowed to cool and hardened at room temperature. The hardened medium was inverted and then incubated at $37{ }^{\circ} \mathrm{C}$ for the sterility assurance test. The microbial nutrient broth $(2 \mathrm{~g})$ was mixed with $250 \mathrm{~mL}$ of sterile distilled water. The mixture was sterilized by autoclaving at $120^{\circ} \mathrm{C}$ for 15 min under 1 bar pressure. The nutrient broth was cooled, and an innoculum from a pure subculture of a C. albicans colon was innoculated into the broth and then diluted threefold, then introduced into the culture medium. Four circular wells were made in each culture medium and $10 \mu \mathrm{L}$ containing $100 \mu \mathrm{g} / \mathrm{mL}$ of pure compounds dissolved in dimethyl sulfoxide (DMSO) was dispensed into each of the three wells in the medium, the fourth one being dispensed with $10 \mu \mathrm{L}$ of DMSO, as a control. After the compounds had diffused into the medium, the culture medium was inverted and incubated at $37{ }^{\circ} \mathrm{C}$ for $24 \mathrm{~h}$. The absence of a clear circular region around the disc loaded with a measured volume of test compound was used as an indicator of growth. The inhibition zone was determined by measuring the diameter in millimetres of the circular region around each well.

3.5 5-(2", $3^{\prime \prime}$-Epoxy-3"'-methylbutyl)-3-(3'-hydroxy-3'methyl-1'acetyloxy-but- $2^{\prime}$-yl)indole (1)

Yield: $10.2 \mathrm{mg}$. Anisaldehyde: brown. Cerium reagent: yellow. MS, $m / z$ (\% rel. int.) $345\left(\mathrm{M}^{+}, 5\right), 330(5), 285$ (8), 270 (8), 244 (5), 227 (100), 212 (40), 198 (25), 184 (38), 172 (40), 156 (100), 143 (38), 115 (18), 83 (15), 59 (38) and 43 (60). ${ }^{1} \mathrm{H}$ and ${ }^{13} \mathrm{C}$ NMR: see Tables 1 and 2.

\subsection{3-(2',3'-Dihydroxy-3'-methylbutyl)-5-(3"- methylcrotonoyl)indole (2)}

Colourless oil. Yield: $8.2 \mathrm{mg}$. Anisaldehyde: brown. Cerium reagent: orange. IR $v_{\max } 3655,3540,1664,1598$ and $1573 \mathrm{~cm}^{-1}$. MS, $\mathrm{m} / \mathrm{z}$ (\% rel. int.) $301\left(\mathrm{M}^{+}, 50\right), 286(10)$, 243 (4), 212 (68), 198 (30), 130 (42), 83 (100), 59 (22) and 55 (23). ${ }^{1} \mathrm{H}$ and ${ }^{13} \mathrm{C}$ NMR: see Tables 1 and 2.
3.7 3,5-Hexalobine C (3)

Colourless oil. Yield: $9.1 \mathrm{mg}$. Anisaldehyde: brown. Cerium reagent: red. IR $v_{\max } 3464,2991$ and $1630 \mathrm{~cm}^{-1}$. MS, $\mathrm{m} / \mathrm{z}$ (\% rel. int.) $285\left(\mathrm{M}^{+}, 98\right), 270$ (60), 242 (98), 214 (58), 156 (50) and 143 (100). ${ }^{1} \mathrm{H}$ and ${ }^{13} \mathrm{C}$ NMR: see Tables 1 and 2.

\subsection{3,5-Hexalobine D (4)}

White needles. Yield: $150 \mathrm{mg}$, m.p $131-133{ }^{\circ} \mathrm{C}$. Anisaldehyde: yellow. Cerium reagent: brown. IR $v_{\max } 3452,2991$, 1644, 1614 and $1571 \mathrm{~cm}^{-1}$. MS, $\mathrm{m} / \mathrm{z}$ (\% rel. int.) $283\left(\mathrm{M}^{+}\right.$, 50), 268 (30), 240 (38), 228 (38), 210 (60), 196 (43), 129 (50) and 83 (100). ${ }^{1} \mathrm{H}$ and ${ }^{13} \mathrm{C}$ NMR: see Tables 1 and 2.

Acknowledgments The Norwegian Agency for International Development (NORAD) through the NORAD Chemistry Project is appreciated for supporting this work through a scholarship grant to H.M.M. The National Institute for Medical Research (NIMR), The Department of Chemistry at the University of Dar es Salaam in Tanzania and the Department of Pharmaceutical Chemistry in the Institute of Pharmacy at Erlangen University in Germany are thanked for supporting the research project.

Open Access This article is distributed under the terms of the Creative Commons Attribution License which permits any use, distribution, and reproduction in any medium, provided the original author(s) and the source are credited.

\section{References}

1. B. Verdcourt, Flora of Tropical East Africa-Annonaceae (Crown Agents, London, 1971)

2. F.R. Irvine, Wood plants of Ghana (Oxford University Press, London, 1961), p. 9

3. C.C. Joseph, M.Sc, thesis, University of Dar es Salaam, Tanzania, 1993

4. H. Achenbach, C. Renner, R. Waibel, Liebigs Annalen, 1327, 1995

5. M. Löwel, Ph.D. thesis, University of Erlangen, Federal Republic of Germany, 1992

6. C. Renner, Ph.D. thesis, University of Erlangen, Federal Republic of Germany, 1986

7. H. Achenbach, M. Löwel, Phytochemistry 40, 967 (1995)

8. D.H. Williams, I. Fleming, Spectroscopic Methods in Organic Chemistry, 4th edn. (McGraw-Hill Book Company, New Delhi, 1989) 